\title{
Trailblazer Barbara Allen-Diaz First Woman to Receive SRM Renner Award
}

\section{By Donna Hemmila}

\section{On the Ground}

- When Barbara Allen-Diaz accepted the 2015 Frederic G. Renner Award at the annual Society of Range Management meeting on February 3, 2015, she made history.

- In the 43 years since the award was established, Allen-Diaz is the first woman to receive this honor, the most prestigious the Society bestows on its members.

Keywords: Barbara Allen-Diaz, Frederic G. Renner Award, SRM awards, University of California.

Rangelands 37(2):81-84

doi: 10.1016/j.rala.2015.01.005

(C) 2015 The Society for Range Management hen Barbara Allen-Diaz accepted the 2015 Frederic G. Renner Award at the annual Society of Range Management meeting on 3 February 2015, she made history. In the 43 years since the award was established, Allen-Diaz is the first woman to receive this honor, the most prestigious the SRM bestows on its members.

"I feel enormously proud," she says. "At the same time, I know I wouldn't be where I am without all the people who supported me, including the many creative and bright grad students I've worked with over the years. I have to give them a lot of credit. Of course, I'm honored to be the first woman recipient."

During a 37-year career as a researcher and educator, Allen-Diaz has earned a reputation as a visionary academic leader, a trailblazing scientist, and a caring mentor who has inspired new generations of students to share her passion for the range management profession.

\section{Early Days}

Allen-Diaz's journey to becoming one of the world's foremost rangeland experts began in the rugged woods and waterways of the Pacific Northwest. Growing up in the small waterfront town of Edmonds, north of Seattle, she learned to love the outdoors through frequent family camping and fishing trips. She enjoyed pheasant hunting with her father, although she wasn't allowed to shoot anything. Her job was to flush the birds out of hiding, a duty happily shared with the family's English Setter Joe.

Other times, her parents, brother, sister and she all piled into their 16-foot, wooden-hull boat to fish for salmon in the rough waters of Puget Sound. Those family excursions sparked a lifelong respect for nature matched only by her love of learning.

Encouraged by her parents, Allen-Diaz studied hard and earned stellar grades. In high school, her first ambition was to be a doctor, before realizing she wanted a career working outdoors.

"Like many of my generation, I wanted to do something to help the world and the environment," she says.

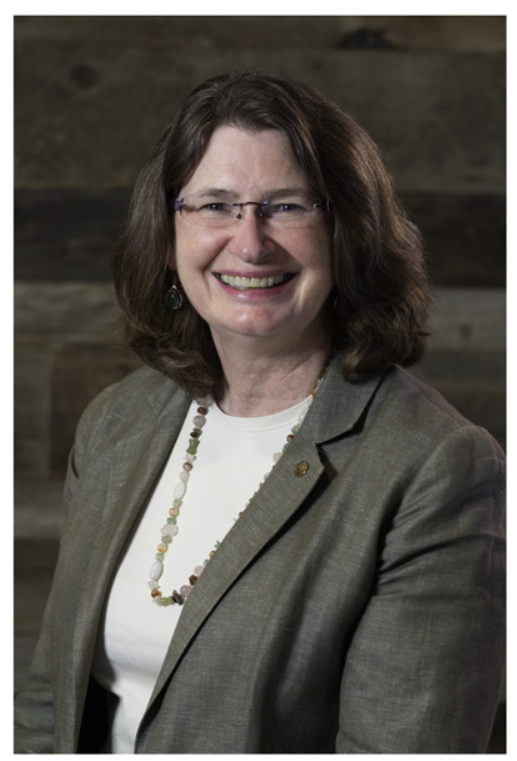

Photo 1. Renner Award recipient Barbara Allen-Diaz is vice-president of UC ANR. 
At the University of Washington, she majored in anthropology and biology and was two quarters away from graduating when her then-husband was accepted to a graduate program at University of California (UC) Berkeley. Allen-Diaz followed him to the campus where she completed a bachelor's degree in 1975 and changed the course of her life.

In search of a graduate program that would satisfy her desire to apply science to the natural world, she found her way to rangeland management through a fortuitous meeting with former SRM President Harold Heady, then associate dean of student affairs in the College of Natural Resources at Berkeley.

Heady, who passed away in 2011 at age 95, reviewed Allen-Diaz's transcripts and told her she could begin a master's program in range management the next day.

Until talking with Heady, she recalls, she didn't know what rangeland management was. But she soon came to appreciate the vast diversity of the discipline and the many aspects of natural science it encompasses. She earned a master's in range management in1978 and a doctorate in wildland resource science in 1980 .

"It's because Harold Heady took a risk and believed in me," she says.

After she graduated from Berkeley, US Forest Service Director Glen Hetzel recruited her as an ecologist based in the San Francisco region. She worked for the Forest Service from 1980 until 1986, when she joined the faculty at UC Berkeley, where she still holds a tenured position in the College of Natural Resources and the Russell Rustici Chair in Rangeland Management.

Throughout her career, Allen-Diaz paved the way for women to succeed in historically male-dominated roles. When she joined the UC, Berkeley faculty, she was the first woman in the United States to receive an academic appointment in range management. Later, she served as chair of the Department of Environmental Science, Policy and Management at Berkeley, and in other administrative positions in the college.

In 2011, after serving in various administrative leadership positions in UC Agriculture and Natural Resources (ANR), she was appointed head of that division, a position equivalent in responsibilities to that of a chancellor in the UC system. She is the first woman ANR vice president in the university's nearly 150 -year history. In that prestigious position, she oversees California's Cooperative Extension Service, nine UC Research and Extension Centers, including the 4-H Youth Development and Master Gardener programs, community food and nutrition programs, and a statewide network of 1,500 researchers and educators.

"The work we do is oriented to finding solutions to pressing issues that affect the land, water, people and communities," she says. "I'm very privileged to lead that."

"Boots on the ground" is a motto heard often among ANR staff. It's an appropriate metaphor for the work they do as well as a comment on Allen-Diaz's down-to-earth practical style. She wears cowboy boots to the office, dividing her time between the UC system-wide Office of the President headquarters in downtown Oakland, and the
UC ANR headquarters in Davis, where many ANR researchers are based. Frequent visits to field stations keep her up to speed on the challenges plaguing the western United States. Drought, wild fires, and climate change are among the issues ANR prioritized in its Strategic Vision 2025 plan-one of the long-range projects Allen-Diaz has led to build healthy communities and to sustain the state's natural ecosystems.

As California's public research university, UC plays a significant role in the state's agriculture industry. Cooperative extension advisors and specialists are active in every county, providing the scientific knowledge needed to improve crop yields, manage pests, develop food safety strategies, and address global food shortages.

During an era of severe state budget cuts to California public higher education, Allen-Diaz made certain ANR remained committed to serving the state's growers and food producers. She never shied away from making hard decisions about the use of diminishing resources.

"When people talk about me, I'm told they refer to me as tough but fair," she says. "I'm okay with that. I'd rather be known as tough and fair than most of the other things one might be known as," she says with a smile.

SRM member and Associate Vice President for UC Cooperative Extension Bill Frost credits Allen-Diaz's leadership for heightening public awareness of rangeland issues and improving California's range resource management.

"Her strategic decisions in funding of competitive grant programs and new cooperative extension positions contributes significantly to continuing impacts on rangeland management by the University of California," he says.

\section{Public Service Research}

In addition to her academic leadership achievements, Allen-Diaz has produced an impressive body of rangeland research, publishing 177 articles, 58 in refereed journals.

"Barbara takes responsibility for things," UC Berkeley professors Jamie Bartolome and Lynn Huntsinger wrote in support of Allen-Diaz's nomination for the Renner Award. "While many of us too easily accept situations that need improvement, Barbara is willing to step up and work to make things better. Compassion, vision, and insight characterize her outstanding leadership."

As a recognized authority on the ecology and management of oak woodland, Allen-Diaz has produced game-changing information on livestock grazing in forests, the relationship of grazing and water quality on annual rangeland, and potential effects of climate change on rangeland ecosystems, to name but a few areas of focus.

"I've done research that dispelled longstanding myths about range management," she said. "That's been satisfying, to provide the scientific data behind management decisions over livestock grazing."

Trekking through the Sierra Nevada on horseback, and later a mountain bike, Allen-Diaz spent 15 years studying the effects of livestock grazing on woodland springs. She was the 
first to provide data to show cattle are not the primary cause of nitrates in those habitats.

In other research studies, she discredited a long-held belief that cattle caused the declines in toad populations in the Sierra Nevada.

"Although her publication record is very significant on its own, Dr. Allen-Diaz is the type of researcher whose influence goes far deeper than the study results and journal publications," says David Lile, SRM Pacific-California Section president. "She is also a leader at engaging people in the process of range management decision making."

In nominating Allen-Diaz for the Renner award, Fee Busby, of Utah State University, and Amy Ganguli, of New Mexico State University, praised Allen-Diaz both for her professional achievements and her caring personality.

"We, the nominators, believe Barbara Allen-Diaz is a special person who has sustained outstanding contributions to our profession and Society," they wrote. "When you see her at SRM meetings she is personable and easy to visit with. She is always interested in you-your work, your family."

They also noted her commitment to sharing the results of her research with land managers and others who may benefit from the practical application of the science her scholarly work uncovers.

"I have the philosophy of collaboration, consensusbuilding, and not being afraid to tackle tough issues," Allen-Diaz says in summing up her approach to the sometimes contentious conflicts that arise over the best use of rangeland resources.

"I've walked the line between the livestock community and environmentalists," she says. "I've thrived professionally by sticking to the scientific data."

Frequently, her research has garnered recognition from her peers. In 2001, SRM gave Allen-Diaz an Outstanding Achievement Award, followed in 2002 by the Range Manager of the Year Award. Although she cherishes those recognitions, one of the highlights of Allen-Diaz's career is winning a Nobel Prize.

In 1994, the Intergovernmental Panel on Climate Change (IPCC) tapped Allen-Diaz to lead the effort to determine how climate change is affecting rangeland environments. She led the international team of scientists that produced the report titled Rangelands in a Changing Climate: Impacts, Adaptations, and Mitigations. In 2007, she was among the scientists who shared in the Nobel Peace Prize awarded to the IPCC and former Vice President Al Gore.

\section{Mentor and Motivator}

Her passion for scientific inquiry and public service has inspired many to follow Allen-Diaz into the rangeland profession. She has mentored more than 50 graduate students, encouraging diversity and work-life balance among her students and early career colleagues.

"Her willingness and capacity to lead continue to inspire and to instill in me the courage to carry out my own vision for

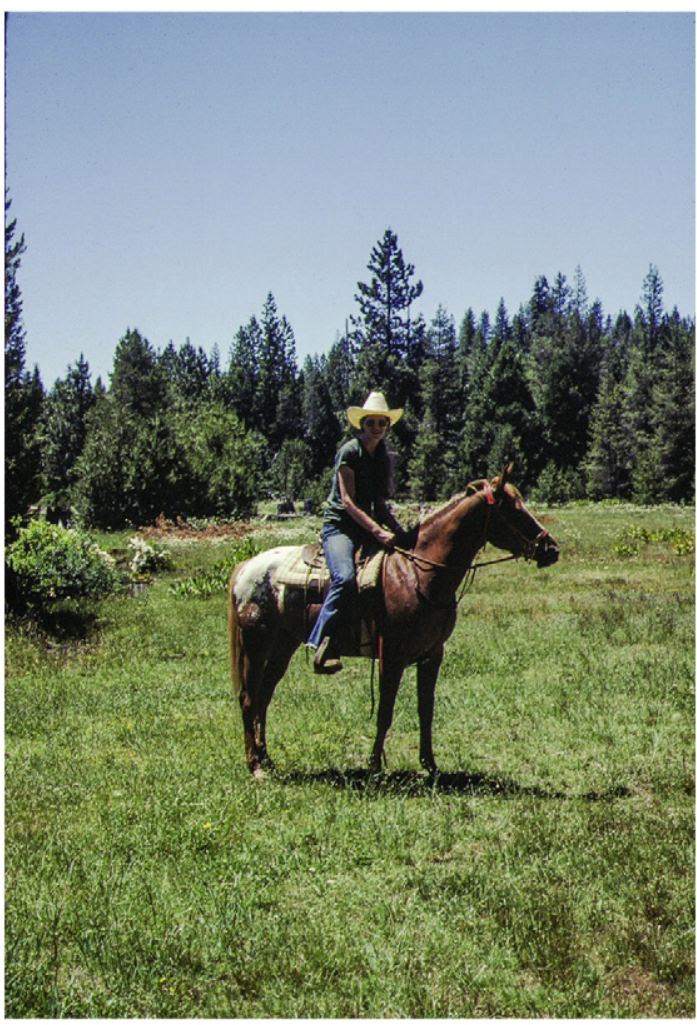

Photo 2. Allen-Diaz and her horse, Ginger, conduct research in 1978.

a diverse and vibrant rangeland profession," says former graduate student Maria Fernandez-Gimenez.

Now a professor of Rangeland Ecology and Management at Colorado State University, Fernandez-Gimenez continues to look to Allen-Diaz as a role model. She talks about the ripple effect her former graduate advisor has had on the profession: "Because she reached out to me as a graduate student, I have in turn recruited some 20 graduate students, including many women, international and indigenous students, into our profession."

\section{Giving Back}

Allen-Diaz has been a member of SRM for 37 years, serving on the boards of directors of both the national organization and the California section. In 1995-1996, she was president of the California section and served many years on its Certified Rangeland Manager Panel. Additionally, she participates in national and regional volunteer activities.

"I really appreciate my professional society and my colleagues in SRM," she says. "I'm committed to the mission and values we all share."

Despite the enormous professional and administrative duties she shoulders, Allen-Diaz makes time for family.

On weekends, she returns to her childhood roots in the Pacific Northwest where she and retired Forest Service 
husband, David Diaz, share 7.5 acres of Oregon oak woodland and pines. There, she puts boots to the ground, driving the tractor and trimming trees with a chainsaw. She still enjoys fishing and tramping through the woods.

The couple's daughter Tianna is a senior at UC San Diego majoring in biology and cognitive science. They also have three grown children and six grandchildren.
"My family is what grounds me," Allen-Diaz says. "They're everything to me."

Author is recently retired speechwriter from the University of California, Office of the President, in Oakland, CA, 94607, USA,dhemmila@comcast.net 